$\begin{array}{ll}\text { Volume } & : 05 \\ \text { Nomor } & : 01 \\ \text { Bulan } & : \text { Januari } \\ \text { Tahun } & : 2019 \\ \text { http } & : \text { //ejurnal.pps.ung.ac.id/index.php/AKSARA/index }\end{array}$

\title{
PENINGKATAN KEMAMPUAN MENULIS NASKAH DRAMA BERDASARKAN CERPEN YANG DIBACA MELALUI STRATEGI STRATA
}

\author{
Salman Suratinoyo \\ SMP Negeri 16 Gorontalo \\ salman@gmail.com
}

Received: 25 November 2018; Revised: 1 Desember 2018; Accepted: 5 Desember 2018

\begin{abstract}
ABSTRAK
Penelitian Tindakan Kelas ini bertujuan meningkatkan kemampuan menulis naskah drama berdasarkan cerpen yang dibaca dengan menggunakan strategi Strata. Penelitian dilaksanakan di SMP Negeri 13 Gorontalo dengan mengambil subjek penelitian pada peserta didik di kelas IX-1 yang berjumlah 31 orang. Pengumpulan data dilakukan dengan menggunakan lembar pengamatan kegiatan guru, lembar pengamatan kegiatan peserta didik, dan tes tertulis. Teknik analisis data menggunakan deskriptif kualitatif dan analisis kuantitatif. Hasil penelitian menunjukkan bahwa penerapan strategi Strata dapat meningkatkan kemampuan menulis naskah drama berdasarkan cerpen yang dibaca. Jika pada hasil tes awal kemampuan peserta didik rata-rata hanya 37,61\% dari 31 orang peserta didik. Setelah diterapkan strategi Strata pada siklus I kemampuan rata-rata peserta didik mengalami peningkatan menjadi $53,74 \%$. Beberapa kekurangan pada siklus I diperbaiki pada siklus II sehingga kemampuan rata-rata peserta didik mengalami peningkatan menjadi 95, $67 \%$.
\end{abstract}

Kata kunci: kemampuan, menulis naskah drama, cerpen

\section{PENDAHULUAN}

Keterampilan menulis merupakan salah satu keterampilan berbahasa yang paling kompleks karena menulis merupakan suatu proses yang menuntut pengalaman, waktu, kesepakatan, latihan serta memerlukan cara berpikir yang teratur untuk mengungkapkannya. Itulah sebabnya, keterampilan menulis perlu mendapat perhatian yang lebih dan sungguh-sungguh sebagai salah satu aspek keterampilan berbahasa. Menurut Akhadiah, dkk (1995:2-3) menulis merupakan suatu proses yaitu proses penulisan. Ini berarti bahwa kita melakukan penulisan dalam beberapa tahap yaitu tahap prapenulisan, tahap penulisan dan tahap revisi.

Menurut Tarigan (2008:12) menulis merupakan kegiatan yang produktif dan ekspresif untuk mengungkapkan ide, pikiran, gagasan dan pengetahuan. Disebut sebagai kegiatan produktif karena kegiatan menulis menghasilkan tulisan, dan disebut sebagai kegiatan yang ekspresif karena kegiatan menulis adalah kegiatan yang mengungkapkan ide, gagasan, pikiran, dan pengetahuan penulis kepada pembaca. Dalam kegiatan menulis, dibutuhkan dasar pengetahuan penulis terhadap kosakata dan struktur kebahasaan.

Salah satu kompetensi dasar yang menuntut ketuntasan belajar peserta didik dalam keterampilan menulis adalah menulis naskah drama berdasarkan cerpen yang dibaca. Realitas yang terjadi di lapangan berdasarkan pengalaman dan pengamatan penulis, masih banyak peserta didik yang belum mampu atau belum tuntas pada kompetensi dasar tersebut. Berdasarkan studi pendahuluan yang dilakukan pada 31 orang peserta didik kelas IX-1 SMP Negeri 13 Gorontalo, diperoleh data bahwa 7 orang peserta didik atau $22.58 \%$ sudah mampu menulis naskah drama berdasarkan cerpen yang dibaca, sedangkan 
masih 24 orang peserta didik atau $77.42 \%$ belum mampu. Selanjutnya peneliti berdiskusi dengan teman atau guru mitra tentang akar penyebab ketidakmampuan peserta didik. Dari hasil diskusi tersebut, diketahui bahwa ketdakmampuan peserta didik disebabkan oleh (1) peserta didik kurang mampu mengidentifikasi pokok-pokok cerita dalam cerpen yang sudah dibaca, (2) peserta didik kurang mampu kemampuan peserta didik mengidentifikasi perbedaan gaya penulisan cerpen dan drama, dan (3) peserta didik kurang mampu menulis naskah drama berdasarkan cerpen yang dibaca.

\section{METODE PENELITIAN}

Penelitian ini menggunakan rancangan Penelitian Tindakan Kelas (PTK) model siklus spiral Kurt Lewin (dalam Sukidin dkk, 2010:45) yang meliputi tahapan perencanaan (planning), tindakan (action), observasi (observation), dan refleksi (reflecting). Penelitian dilaksanakan di SMP Negeri 13 Gorontalo. Adapun yang menjadi subjek penelitian adalah peserta didik di kelas IX-1 yang berjumlah 31 orang, terdiri atas 11 orang laki-laki dan 20 orang perempuan.

Pengumpulan data dilakukan dengan beberapa jenis instrumen. Pertama, lembar pengamatan kegiatan guru yang digunakan untuk mengamati dan menilai aspek-aspek pembelajaran yang dilaksanakan guru. Kedua, lembar pengamatan kegiatan peserta didik yang digunakan untuk mengamati dan menilai kegiatan peserta didik selama mengikuti pembelajaran. Ketiga, tes tertulis untuk mengetahui kemampuan peserta didik pada materi yang telah disajikan.

Analisis kualitatif digunakan untuk mendeskripsikan setiap tahapan proses pembelajaran baik pada siklus I maupun siklus II. Selain itu, analisis kualitatif digunakan untuk mendeskripsikan secara detail capaian peningkatan kemampuan peserta didik menulis naskah drama berdasarkan cerpen yang dibaca. Analisis kuantitatif digunakan untuk mengukur skor perolehan hasil belajar peserta didik baik pada masing-masing indicator maupun untuk mengukur capaian hasil belajar rata-rata peserta didik.

\section{HASIL PENELITIAN DAN PEMBAHASAN}

Sebelum melaksanakan penelitian tindakan, peneliti melakukan tes awal terhadap subjek penelitian. Tes awal dimaksudkan untuk mengetahui kemampuan awal peserta didik menulis naskah drama berdasarkan cerpen yang dibaca sebelum diterapkan strategi Strata.

Tabel 2. Persentase Rata-Rata Hasil Tes Awal

\begin{tabular}{|c|c|c|c|}
\hline Aspek yang Dinilai & Kriteria Penilaian & $\begin{array}{l}\text { Jumlah } \\
\text { Siswa }\end{array}$ & $\begin{array}{l}\mathrm{Jmlh} \\
(\%)\end{array}$ \\
\hline $\begin{array}{l}\text { 1. Kemampuan peserta didik mengidentifikasi } \\
\text { pokok-pokok cerita dalam cerpen yang } \\
\text { sudah dibaca dengan menggunakan strategi } \\
\text { strata. }\end{array}$ & $\begin{array}{l}\text { 1. Sangat tepat } \\
\text { 2. Tepat } \\
\text { 3. Kurang tepat } \\
\text { 4. Tidak tepat } \\
\text { 5. Tidak ada jawaban }\end{array}$ & $\begin{array}{l}4 \\
9 \\
15 \\
3 \\
0 \\
\end{array}$ & $\begin{array}{l}12.90 \% \\
29.03 \% \\
48.39 \% \\
9.68 \% \\
0 \% \\
\end{array}$ \\
\hline $\begin{array}{l}\text { 2. Kemampuan peserta didik mengidentifikasi } \\
\text { perbedaan gaya penulisan cerpen dan drama } \\
\text { dengan menggunakan strategi strata. }\end{array}$ & $\begin{array}{l}\text { 1. Sangat tepat } \\
\text { 2. Tepat } \\
\text { 3. Kurang tepat } \\
\text { 4. Tidak tepat } \\
\text { 5. Tidak ada jawaban }\end{array}$ & $\begin{array}{l}3 \\
7 \\
17 \\
4 \\
0 \\
\end{array}$ & $\begin{array}{l}9.68 \% \\
22.58 \% \\
54.84 \% \\
12.90 \% \\
0 \%\end{array}$ \\
\hline $\begin{array}{l}\text { 3. Kemampuan peserta didik menulis naskah } \\
\text { drama berdasarkan cerpen yang dibaca } \\
\text { dengan menggunakan strategi strata. }\end{array}$ & $\begin{array}{l}\text { 1. Sangat baik } \\
\text { 2. Baik } \\
\text { 3. Kurang baik } \\
\text { 4. Tidak baik } \\
\text { 5. Tidak ada jawaban }\end{array}$ & $\begin{array}{l}4 \\
8 \\
14 \\
5 \\
0 \\
\end{array}$ & $\begin{array}{l}12.90 \% \\
25.81 \% \\
45.16 \% \\
16.13 \% \\
0 \%\end{array}$ \\
\hline
\end{tabular}




$\begin{array}{ll}\text { Volume } & : 05 \\ \text { Nomor } & : 01 \\ \text { Bulan } & : \text { Januari } \\ \text { Tahun } & : 2019 \\ \text { http } & : / / \text { ejurnal.pps.ung.ac.id/index.php/AKSARA/index }\end{array}$

Data tabel 2 menunjukkan bahwa pencapaian peserta didik dalam menulis naskah drama berdasarkan cerpen yang dibaca. Pada indikator I, hanya 4 orang peserta didik atau $12.0 \%$ yang mencapai kategori sangat tepat, kategori tepat dicapai oleh 9 orang peserta didik atau $23.03 \%$, kategori kurang tepat masih dominan yaitu 15 orang peserta didik atau $48.39 \%$, kategori tidak tepat berjumlah 3 orang peserta didik atau sekitar $9.68 \%$, sedangkan yang tidak dapat menjawab tidak ada. Selanjutnya indikator II, dari 31 orang peserta didik yang berhasil mencapai kategori sangat tepat hanya 3 orang atau $9.68 \%$, kategori tepat baru dicapai oleh 7 orang atau 22.58\%, 17 orang atau 54.84\% mencapai kategori kurang tepat, 4 orang atau $12.90 \%$ yang tidak tepat, serta yang tidak dapat menjawab tidak ada. Sementara pada indikator III, peserta didik yang mencapai kategori sangat baik hanya 4 orang atau $12.90 \%$, kategori baik berjumlah 8 orang atau $25.81 \%$, kategori kurang baik lebih mendominasi yaitu 14 orang atau $45.16 \%$, kategori tidak baik masih berjumlah 5 orang atau $16.13 \%$, sedangkan yang tidak ada jawaban tidak ada.

\section{Pelaksanaan Penelitian Siklus I Persiapan dan Perencanaan}

Berdasarkan data tes awal, peneliti berdiskusi dengan guru mitra untuk merancang tindakan untuk meningkatkan kemampuan peserta didik dalam menulis naskah drama berdasarkan cerpen yang dibaca. Setelah diidentifikasi masalah, maka peneliti menganalisis penyebab timbulnya masalah, menentukan faktor-faktor yang diduga sebagai penyebab masalah. Kemudian membuat skenario pembelajaran yang menggunakan strategi Strata sekaligus membuat alat observasi dan evaluasi.

\section{Tahap Tindakan}

Pelaksanaan tindakan pada siklus I dilaksanakan dalam 2 (dua) kali pertemuan. Berikut ini diuraikan proses pembelajaran per pertemuan.

\section{Siklus I, Pertemuan I}

Pelaksanaan pembelajaran pada pertemuan I dilaksanakan selama 2 jam $(2 \times 40$ menit) dengan kompetensi dasar "Menulis naskah drama berdasarkan cerpen yang dibaca" dengan indikator: (1) mampu mengidentifikasi pokok-pokok cerita dalam cerpen, (2) mampu mengidentifikasi perbedaan gaya penulisan cerpen dan drama. Untuk mencapai tujuan dan indikator keberhasilan dalam pembelajaran siklus I tersebut peneliti menggunakan metode/strategi strata. Kegiatan pelaksanaan pembelajaran dilaksanakan dalam 3 (tiga) tahap yaitu kegiatan awal, inti, dan akhir/penutup.

Setelah hasil pekerjaan peserta didik diperiksa pada pertemuan ke I siklus I, maka diperoleh sekitar 17 orang peserta didik atau 54.84\% yang sudah mampu mengidentifikasi pokok-pokok cerpen dan mengidentifikasi gaya penulisan dengan sangat baik dan baik. Sedangkan sisanya 14 orang atau $45.16 \%$ dinyatakan belum mampu.

Siklus I, Pertamuan II

Pelaksanaan pembelajaran pada pertemuan II dilaksanakan selama 3 jam pembelajaran (3x40 menit) dengan kompetensi dasar menulis naskah drama berdasarkan cerpen yang dibaca. Adapun indikator keberhasilan yang dicapai dalam pembelajaran ini adalah mampu menulis naskah drama berdasarkan cerpen yang dibaca. Untuk mencapai indikator keberhasilan dalam pembelajaran siklus I tersebut peneliti menggunakan metode/strategi strata. Kegiatan pelaksanaan pembelajaran dilaksanakan dalam 3 (tiga) tahap yaitu kegiatan awal, inti, dan akhir/penutup. 


$\begin{array}{ll}\text { Volume } & : 05 \\ \text { Nomor } & : 01 \\ \text { Bulan } & : \text { Januari } \\ \text { Tahun } & : 2019 \\ \text { http } & : / / \text { ejurnal.pps.ung.ac.id/index.php/AKSARA/index }\end{array}$

Setelah hasil pekerjaan peserta didik diperiksa pada pertemuan ke II siklus I, kemampuan peserta didik menulis naskah drama berdasarkan cerpen yang dibaca dengan menggunakan strategi strata, yang sangat baik dalam menulis naskah drama baru mencapai 3 orang atau $9.68 \%$, baik dalam menulis naskah drama berdasarkan cerpen yang dibaca ada 13 orang atau $41.94 \%$, serta yang kurang baik dalam menulis naskah drama yaitu 10 orang atau $32.26 \%$, serta yang tidak baik masih ada 5 orang atau $16.13 \%$, dan yang tidak ada jawaban tidak ada.

\section{Tahap Observasi}

Untuk mengetahui peningkatan kemampuan menulis naskah drama berdasarkan cerpen yang dibaca, maka pada akhir sikius I diadakan evaluasi tertulis. Tes yang diberikan adalah sebuah cerpen, lalu peserta didik membaca dengan cermat dan peserta didik menulis naskah drama berdasarkan cerpen yang dibaca setelah itu cerpen diubah menjadi sebuah drama dengan langkah-langkah strategi strata yang dimulai dari penjelajahan, kemudian interpretasi dan re-kreasi atau berkreasi mengembangkan daya nalar serta kemampuan peserta didik mengubah karya sastra berbentuk cerpen ke dalam drama.

Hasil pekerjaan peserta didik diperiksa dengan menggunakan rubrik penilaian aspek menulis. Hasil tersebut secara sederhana dapat dilihat pada tabel 3 berikut.

Tabel 3. Persentase Rata-rata Hasil Evaluasi Belajar pada Siklus I

\begin{tabular}{|c|c|c|c|}
\hline Aspek yang Dinilai & Kriteria penilaian & $\begin{array}{l}\text { Jumlah } \\
\text { Siswa }\end{array}$ & $\begin{array}{l}\text { Jmlh } \\
(\%)\end{array}$ \\
\hline $\begin{array}{l}\text { 1. Kemampuan peserta } \text { didik } \\
\text { mengidentifikasi pokok-pokok cerita } \\
\text { dalam cerpen yang sudah dibaca } \\
\text { dengan menggunakan strategi strata. }\end{array}$ & $\begin{array}{l}\text { 1. Sangat tepat } \\
\text { 2. Tepat } \\
\text { 3. Kurang tepat } \\
\text { 4. Tidak tepat } \\
\text { 5. Tidak ada jawaban }\end{array}$ & $\begin{array}{l}11 \\
6 \\
11 \\
3 \\
0 \\
\end{array}$ & $\begin{array}{l}35.48 \% \\
19.35 \% \\
35.48 \% \\
9.68 \% \\
0 \% \\
\end{array}$ \\
\hline 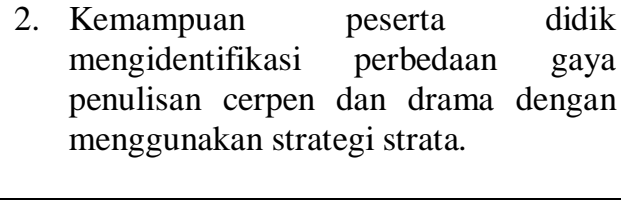 & $\begin{array}{l}\text { 1. Sangat tepat } \\
\text { 2. Tepat } \\
\text { 3. Kurang tepat } \\
\text { 4. Tidak tepat } \\
\text { 5. Tidak ada jawaban }\end{array}$ & $\begin{array}{l}5 \\
12 \\
12 \\
2 \\
0 \\
\end{array}$ & $\begin{array}{l}16.13 \% \\
38.71 \% \\
38.71 \% \\
6.45 \% \\
0 \% \\
\end{array}$ \\
\hline $\begin{array}{l}\text { 3. Kemampuan peserta didik menulis } \\
\text { naskah drama berdasarkan cerpen yang } \\
\text { dibaca dengan menggunakan strategi } \\
\text { strata. }\end{array}$ & $\begin{array}{ll}\text { 1. } & \text { Sangat tepat } \\
\text { 2. } & \text { Tepat } \\
\text { 3. } & \text { Kurang tepat } \\
\text { 4. } & \text { Tidak tepat } \\
\text { 5. } & \text { Tidak ada jawaban }\end{array}$ & $\begin{array}{l}3 \\
13 \\
10 \\
5 \\
0 \\
\end{array}$ & $\begin{array}{l}9.68 \% \\
41.94 \% \\
32.26 \% \\
16.13 \% \\
0 \% \\
\end{array}$ \\
\hline
\end{tabular}

Data pada tabel 3 di atas menunjukkan hasil evaluasi belajar peserta didik pada siklus I. Dari tiga indikator yang dinilai, indikator I terdapat 11 orang peserta didik $(35.48 \%)$ yang mencapai kategori sangat tepat, 6 orang peserta didik $(19.35 \%)$ mencapai kategori tepat, 11 orang peserta didik $(35.48 \%)$ mencapai kategori kurang tepat, 3 orang peserta didik $(9.68 \%)$ berada pada kategori tidak tepat, serta tidak seorang pun yang tidak ada jawaban. Indikator II, dari 31 orang pesereta didik yang berada pada kategori sangat tepat adalah 5 orang atau $16.13 \%$, kategori tepat mencapai 12 orang atau $38.71 \%$, kategori kurang tepat berjumlah 12 orang atau $38.71 \%$, hanya 2 orang atau $6.45 \%$ yang berkategori tidak tepat, serta yang tidak dapat menjawab tidak ada. Indikator III, peserta didik yang memperoleh nilai sangat tepat mencapai 3 orang atau 9.68\%, kategori tepat dibaca ada 13 orang atau $41.94 \%$, serta yang kurang baik dalam menulis naskah drama yaitu 10 orang 


$\begin{array}{ll}\text { Volume } & : 05 \\ \text { Nomor } & : 01 \\ \text { Bulan } & : \text { Januari } \\ \text { Tahun } & : 2019 \\ \text { http } & : / / \text { ejurnal.pps.ung.ac.id/index.php/AKSARA/index }\end{array}$

atau $32.26 \%$, serta yang tidak baik masih ada 5 orang atau $16.13 \%$, dan yang tidak ada jawaban tidak ada.

\section{Pelaksanaan Penelitian Siklus II \\ Tahap Persiapan dan Perencanaan}

Berdasarkan hasil refleksi sikius I, maka ditetapkan rencana-rencana sebagai berikut.

a. Memperbaiki kekurangan seperti mengidentifikasi pokok-pokok cerpen agar sebagaian besar mencapai sangat tepat, demikian juga dengan mengidentifikasi gaya penulisan cerpen serta memperbaiki kemampuan menulis naskah drama dan menyempurnakan kelemahan pada aspek-aspek pelaksanaan kegiatan guru dan kegiatan peserta didik dalam proses belajar mengajar.

b. Mengamati setiap peserta didik dan kelompok secara seksama dalam proses belajar mengajar

\section{Tahap Tindakan}

Siklus II, Pertamuan I

Pelaksanaan pembelajaran pada pertemuan I dilaksanakan selama 2 jam $(2 \mathrm{x} 40$ menit) dengan kompetensi dasar menulis naskah drama berdasarkan cerpen yang dibaca. Indikator keberhasilan yang dicapai dalam pembelajaran ini adalah (1) mampu mengidentifikasi pokok-pokok cerita dalam cerpen, (2) mampu mengidentifikasi perbedaan gaya penulisan cerpen dan drama, untuk mencapai tujuan dan indikator keberhasilan dalam pembelajaran siklus I tersebut peneliti menggunakan metode/strategi strata.

Setelah hasil pekerjaan peserta didik diperiksa pada pertemuan ke I siklus II, pada indikator I terdapat 20 orang peserta didik $(64.52 \%)$ yang mencapai kategori sangat tepat, 11 orang peserta didik (35.48\%) mencapai kategori tepat, sedangkan yang mencapai kurang tepat, tidak tepat dan tidak ada jawaban sudah tidak ada lagi. Pada indikator II, dari 31 orang pesereta didik yang berada pada kategori sangat tepat mencapai 7 orang atau $22.58 \%$, sedang untuk yang tepat adalah 25 orang atau $80.65 \%$, dan tidak seorangpun yang berada pada kategori kurang tepat, tidak tepat serta yang tidak dapat menjawab. Siklus II, Pertamuan II

Pelaksanaan pembelajaran pada pertemuan II dilaksanakan selama 3 jam pembelajaran (3x40 menit) dengan kompetensi dasar menulis naskah drama berdasarkan cerpen yang dibaca. Indikator keberhasilan yang dicapai dalam pembelajaran ini adalah mampu menulis naskah drama berdasarkan cerpen yang dibaca. Untuk itu, peneliti menggunakan metode/strategi strata. Setelah hasil pekerjaan peserta didik diperiksa pada pertemuan ke II siklus II, capaian indikator III adalah, peserta didik yang mencapai kategori sangat baik dalam menulis naskah drama sudah meningkat menjadi 2 orang atau $6.45 \%$, kategori baik mencapai 25 orang atau $80.65 \%$, serta kategori kurang baik hanya 4 orang atau $12.90 \%$, sedangkan kategori tidak baik dan yang tidak memberikan jawaban, tidak ada.

\section{Tahap Observasi}

Untuk mengetahui peningkatan kemampuan menulis naskah drama berdasarkan cerpen yang dibaca, maka pada akhir sikius II diadakan evaluasi tertulis. Tes yang diberikan adalah sebuah cerpen, lalu peserta didik membaca dengan cermat dan peserta didik menulis naskah drama berdasarkan cerpen yang dibaca lalu cerpen diubah menjadi sebuah naskah drama dengan langkah-langkah strategi strata yang dimulai dari 
penjelajahan, kemudian interpretasi dan re-kreasi atau berkreasi mengembangkan daya nalar serta kemampuan peserta didik mengubah karya sastra berbentuk cerpen ke dalam drama.

Hasil pekerjaan peserta didik diperiksa dengan menggunakan rubrik penilaian aspek menulis. Hasil tersebut secara sederhana dapat dilihat pada tabel 6. berikut.

Tabel 4. Persentase Rata-rata Hasil Evaluasi Belajar pada Siklus II

\begin{tabular}{|l|l|l|l|}
\hline Aspek yang Dinilai & Kriteria Penilaian & $\begin{array}{l}\text { Jumlah } \\
\text { Siswa }\end{array}$ & $\begin{array}{l}\text { Jmlh } \\
(\%)\end{array}$ \\
\hline 1. Kemampuan peserta didik mengidentifikasi & 1. Sangat tepat & 20 & $64.52 \%$ \\
pokok-pokok cerita dalam cerpen yang & 2. Tepat & 11 & $35.48 \%$ \\
sudah dibaca dengan menggunakan strategi & 3. Kurang tepat & 0 & $0 \%$ \\
strata. & 4. Tidak tepat & 0 & $0 \%$ \\
& 5. Tidak ada jawaban & 0 & $0 \%$ \\
\hline 2. Kemampuan peserta didik mengidentifikasi & 1. Sangat tepat & 7 & $22.58 \%$ \\
perbedaan gaya penulisan cerpen dan drama & 2. Tepat & 0 & $80.65 \%$ \\
dengan menggunakan strategi strata. & 3. Kurang tepat & 0 & $0 \%$ \\
& 4. Tidak tepat & 0 & $0 \%$ \\
\hline 3. Kemampuan peserta didik menulis naskah & 5. Tidak ada jawaban & 1. Sangat tepat & $6.45 \%$ \\
drama berdasarkan cerpen yang dibaca & 2. Tepat & 25 & $80.65 \%$ \\
dengan menggunakan strategi strata. & 3. Kurang tepat & 0 & $12.90 \%$ \\
& 4. Tidak tepat & $0 \%$ \\
\hline
\end{tabular}

Data pada tabel 4 di atas menunjukkan hasil tes kemampuan menulis naskah drama berdasarkan cerpen yang dibaca oleh peserta didik pada sikius II. Indikator I, terdapat 20 orang peserta didik $(64.52 \%)$ yang mencapai kategori sangat tepat, 11 orang peserta didik $(35.48 \%)$ mencapai kategori tepat, sedangkan yang mencapai kategori kurang tepat, tidak tepat dan tidak ada jawaban sudah tidak ada lagi. Indikator II, dari 31 orang pesereta didik yang mencapai kategori sangat tepat adalah 7 orang atau $22.58 \%$, sedang untuk kategori tepat adalah 25 orang atau $80.65 \%$, dan tidak seorangpun yang berada pada kategori kurang tepat, tidak tepat serta yang tidak dapat menjawab. Indikator III, peserta didik yang memperoleh kategori sangat baik meningkat menjadi 2 orang atau $6.45 \%$, kategori baik adalah 25 orang atau $80.65 \%$, serta kategori kurang baik dalam menulis naskah drama berdasarkan cerpen yang dibaca yaitu 4 orang atau $12.90 \%$, serta yang tidak baik dan yang tidak ada jawaban tidak ada.

Data di atas menunjukkan adanya peningkatan yang signifikan terhadap kemampuan peserta didik menulis naskah drama berdasarkan cerpen yang dibaca. Peningkatan keberhasilan secara klasikal dari $58.06 \%$ pada siklus I menjadi $87.09 \%$ pada siklus II. Dengan demikian, terjadi peningkatan sekitar $29.03 \%$.

\section{Tahap Refleksi}

Bertolak dari hasil evaluasi dan pengamatan proses belajar mengajar siklus II yang dikemukakan di atas, maka peneliti berdiskusi dengan guru mitra untuk mengetahui hasil kemampuan peserta didik menulis naskah drama berdasarkan cerpen yang dibaca. Halhal yang belum dilakukan oleh guru dalam proses belajar mengajar siklus I sudah diperbaiki pada siklus II ini, sehingga dalam pelaksanaan pembelajaran siklus II sudah mengalami peningkatan. 
Pengamatan guru mitra terhadap proses belajar yang dilakukan oleh peneliti di dalam kelas menggambarkan bahwa sebagian besar kegiatan didalam kelas sudah terlaksana dengan sangat baik seperti (1) apersepsi (2) menyampaikan kompetensi dasar, (3) menyampaikan tujuan pembelajaran, (4) menyampaikan indikator pembelajaran, (5) peneliti menugasi peserta didik membuat pertanyaan sehubungan dengan isi cerpen, (6) peneliti menugaskan peserta didik menganalisis unsur-unsur yang membangun sebuah cerpen (interpretasi), (7) tiap kelompok dibimbing untuk mengubah teks cerpen menjadi naskah drama (re-kreasi), (8) menutup pelajaran. Selanjutnya aspek yang sudah terlaksana dengan baik adalah (1) peneliti membagi kelompok dan membagi teks cerpen, (2) peneliti memberi kesempatan pada peserta didik membaca cerpen secara keseluruhan (penjelajahan), (3) peneliti memberikan kesempatan pada peserta didik melakukan penafsiran terhadap isi cerpen, (4) masing-masing kelompok ditugasi mempresentasikan hasil penjelajahan dan interpretasi teks cerpen.

\section{PEMBAHASAN}

Kemampuan peserta didik menulis naskah drama berdasarkan cerpen yang dibaca dapat diukur dari 3 indikator, yaitu (1) kemampuan peserta didik mengidentifikasi pokokpokok cerita dalam cerpen yang sudah dibaca, (2) kemampuan peserta didik mengidentifikasi perbedaan gaya penulisan cerpen dan drama, dan (3) kemampuan peserta didik menulis naskah drama berdasarkan cerpen yang dibaca. Berdasarkan hasil penelitian tindakan kelas dengan menerapkan strategi Strata, kemampuan peserta didik mengalami peningkatan pada masing-masing indikator tersebut. Hal tersebut dapat dilihat pada data grafik 1 di bawah ini.

Grafik 1. Peningkatan Kemampuan Indikator I

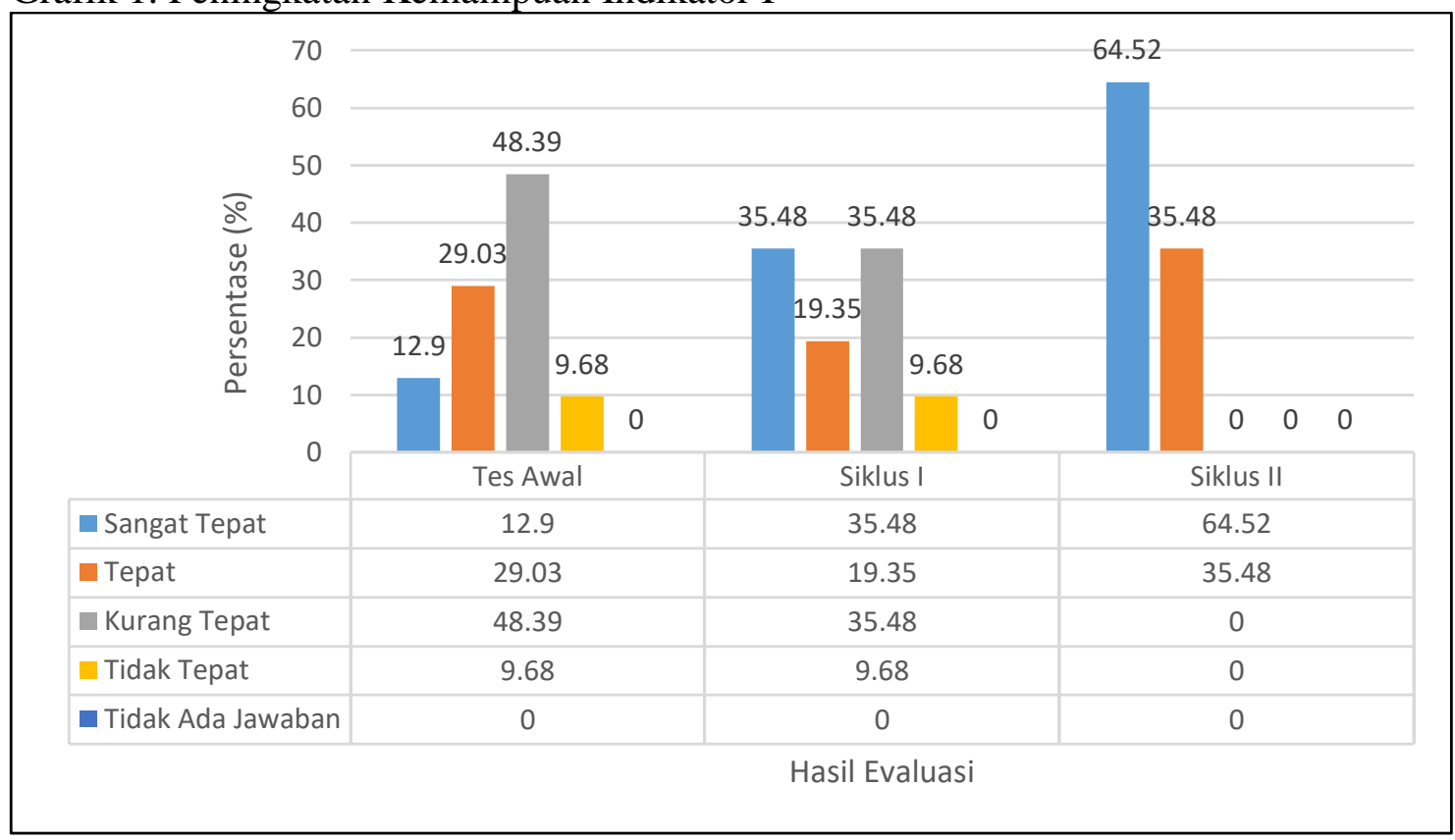

Gambar grafik 1 di atas menunjukkan kemampuan peserta didik mengidentifikasi pokok-pokok cerpen yang dibaca mengalami peningkatan yang signifikan. Jika pada tes awal peserta didik yang mampu (sangat tepat dan tepat) hanya berjumlah 13 orang atau $41,93 \%$ dari 31 orang peserta didik, setelah diterapkan strategi Strata semua peserta didik atau $100 \%$ telah tuntas atau mampu pada indikator ini. 
Grafik 2. Peningkatan Kemampuan Indikator II

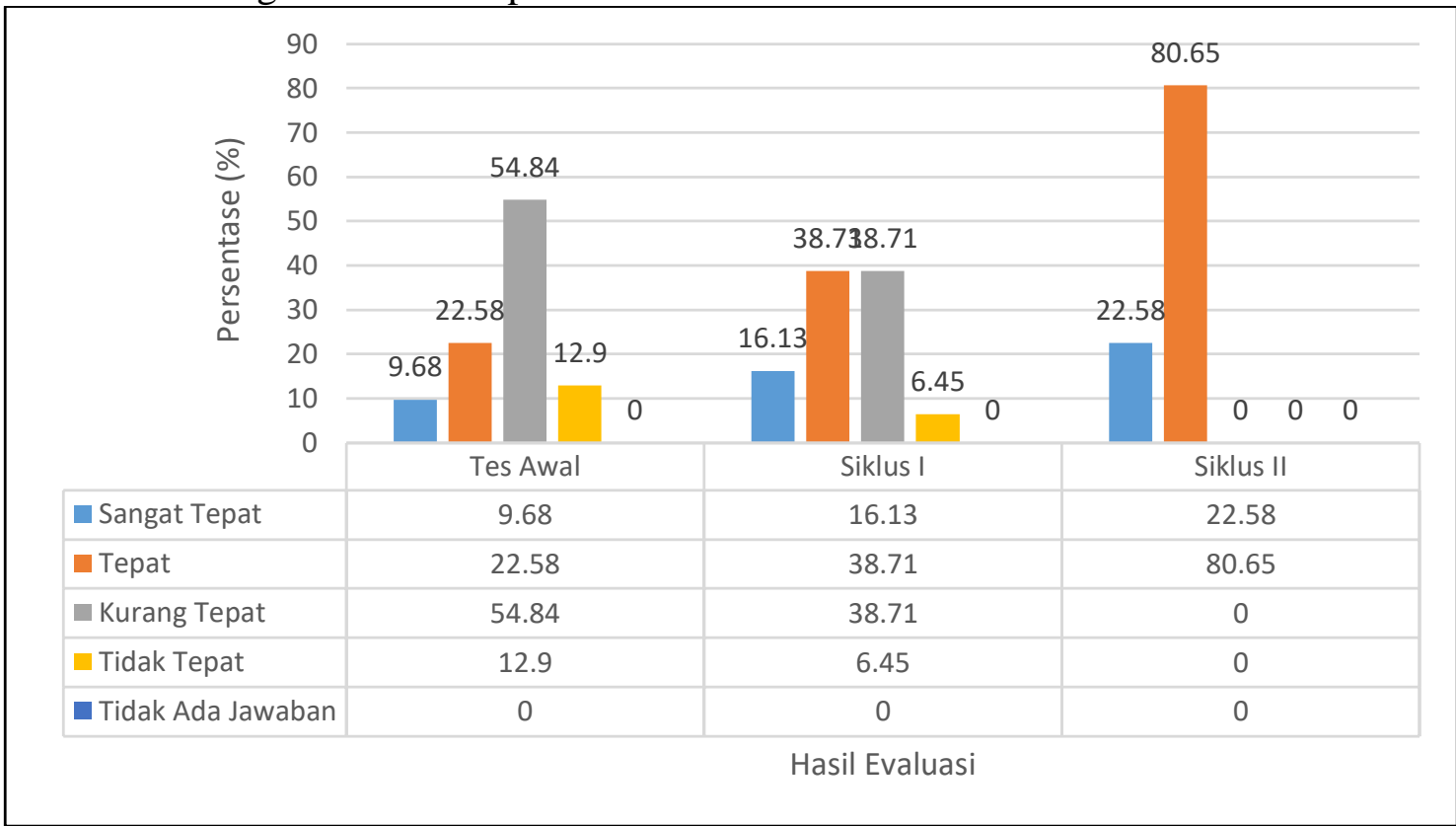

Data grafik 2 di atas menunjukkan bahwa kemampuan peserta didik mengidentifikasi perbedaan gaya penulisan cerpen dan drama mengalami peningkatan. Pada tes awal, peserta didik yang mampu (sangat tepat dan tepat) hanya berjumlah 10 orang atau 32,26\% dari 31 orang peserta didik. Setelah diterapkan strategi Strata, semua peserta didik atau $100 \%$ tuntas pada indikator ini.

Grafik 3. Peningkatan Kemampuan Indikator III

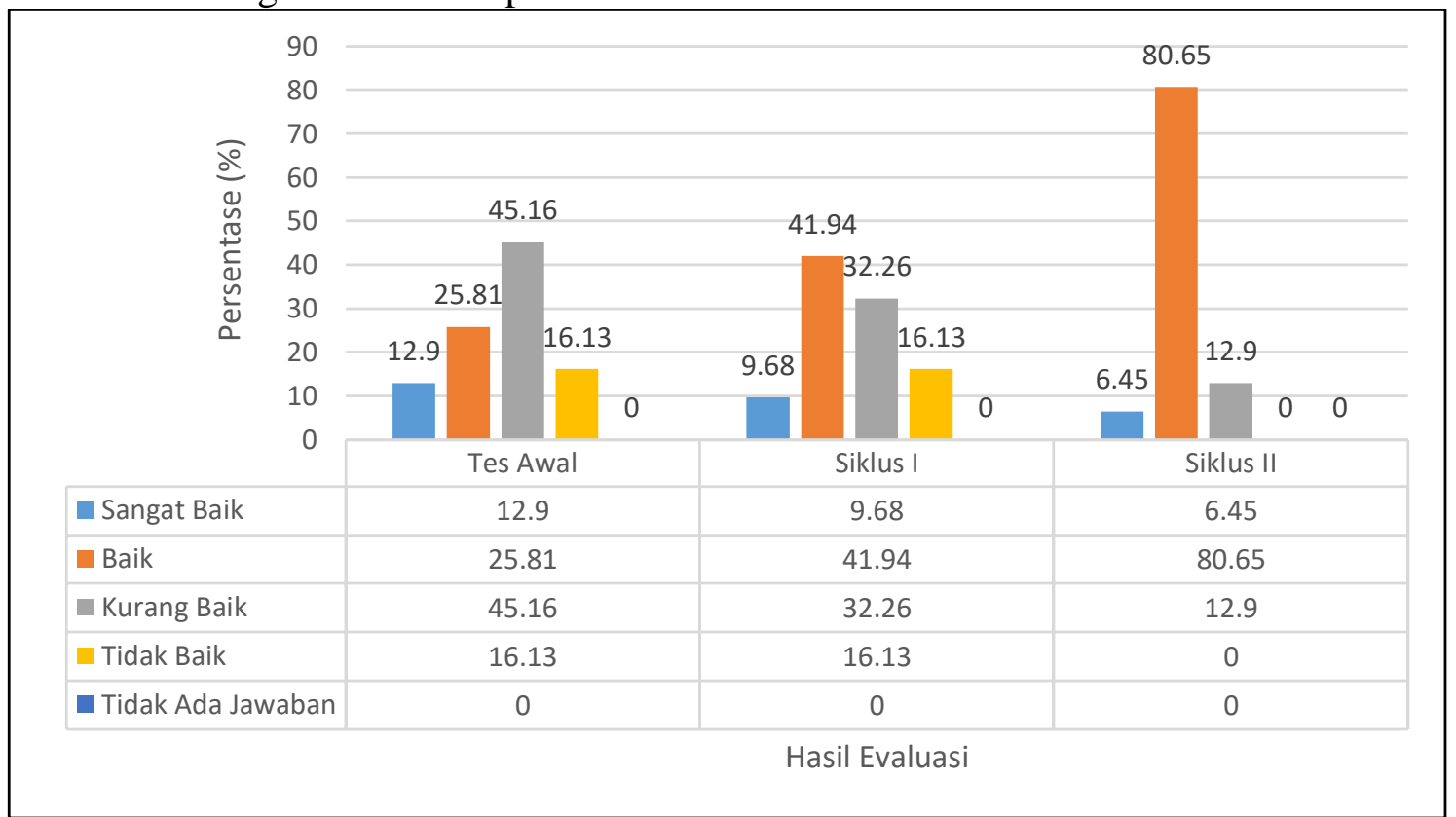

Secara umum, kemampuan peserta didik menulis naskah drama berdasarkan cerpen yang dibaca mengalami peningkatan. Pada tes awal, peserta didik yang mampu menulis naskah drama (sangat baik dan baik) hanya berjumlah 12 orang atau 38,71\% dari jumlah 31 orang peserta didik. Setelah dilakukan tindakan penerapan strategi Strata, kemampuan 


$\begin{array}{ll}\text { Volume } & : 05 \\ \text { Nomor } & : 01 \\ \text { Bulan } & : \text { Januari } \\ \text { Tahun } & : 2019 \\ \text { http } & : / / \text { ejurnal.pps.ung.ac.id/index.php/AKSARA/index }\end{array}$

peserta didik mengalami peningkatan menjadi 27 orang atau 87,1\%, sedangkan sisanya 4 orang atau $12,9 \%$ masih berada pada kategori kurang baik.

Berdasarkan data kemampuan peserta didik pada masing-masing indikator, maka secara umum kemampuan peserta didik menulis naskah drama berdasarkan cerpen yang dibaca setelah diterapkan strategi Strata mengalami peningkatan. Hal tersebut dapat dilihat pada grafik 4 berikut ini.

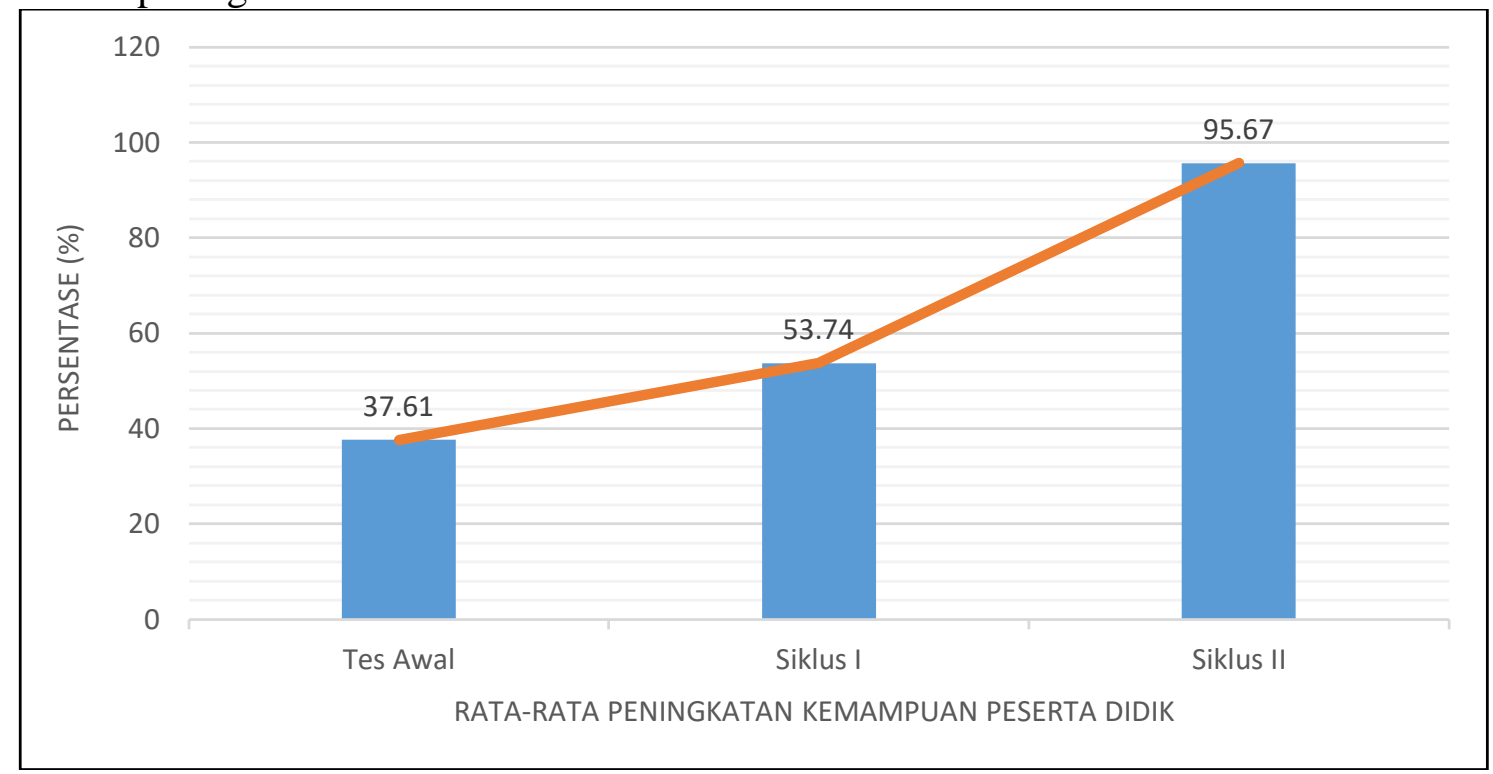

Hasil tes awal kemampuan peserta didik rata-rata hanya 37,61\% dari 31 orang peserya didik. Setelah diterapkan strategi Strata pada siklus I kemampuan rata-rata peserta didik mengalami peningkatan menjadi 53,74\%. Beberapa kekurangan pada siklus I diperbaiki pada siklus II sehingga kemampuan rata-rata peserta didik mengalami peningkatan menjadi 95,67\%. Dengan demikian, penerapan strategi Strata dapat meningkatkan kemampuan peserta didik menulis naskah drama berdasarkan cerpen yang dibaca.

\section{PENUTUP}

Berdasarkan hasil penelitian disimpulkan bahwa penerapan strategi Strata dapat meningkatkan kemampuan menulis naskah drama berdasarkan cerpen yang dibaca. Indikator I, kemampuan peserta didik mengidentifikasi pokok-pokok cerpen yang dibaca mengalami peningkatan mencapai $100 \%$. Indicator II, kemampuan peserta didik mengidentifikasi perbedaan gaya penulisan cerpen dan drama mengalami peningkatan hingga $100 \%$. Indikator III, kemampuan peserta didik menulis naskah drama berdasarkan cerpen yang dibaca mengalami peningkatan menjadi $87,1 \%$. Secara keseluruhan, rata-rata kemampuan peserta didik menulis naskah drama berdasarkan cerpen mengalami peningkatan dari $37,61 \%$ tes awal menjadi 53,74\% pada siklus I, dan setelah beberapa kekurangan pada siklus I diperbaiki pada siklus II sehingga kemampuan rata-rata peserta didik mengalami peningkatan menjadi 95,67\%. 


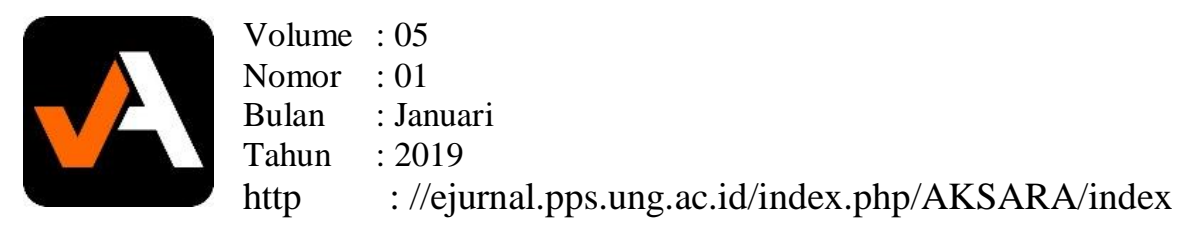

\section{DAFTAR PUSTAKA}

Akhadiah, Sabarti, dkk. 1995. Pembinaan Kemampuan Menulis Bahasa Indonesia. Jakarta: Erlangga.

Sukidin, dkk. 2010. Manajemen Penelitian Tindakan Kelas. Jakarta: Insan Cendekia.

Tarigan, Henry Guntur. 2008. Menulis: Suatu Keterampilan dalam Berbahasa). Bandung: Angkasa.

Waluyo, Herman. 2006. Drama: Naskah Pementasan dan Pengajarannya. Surakarta: UNS Press. 